\title{
Marine Organisms as Biomedical Resources Enrich Quality of Life
}

\author{
Silpa Somavarapu \\ Department of Food Technology, Vikrama Simhapuri University, Nellore, India
}

Email address:

Silpasomavarapu1981@gmail.com

To cite this article:

Silpa Somavarapu. Marine Organisms as Biomedical Resources Enrich Quality of Life. Advances in Biomechanics.

Vol. 5, No. 5, 2017, pp. 62-69. doi: 10.11648/j.cbb.20170505.12

Received: September 10, 2017; Accepted: September 10, 2017; Published: November 27, 2017

\begin{abstract}
The Ocean, called the 'mother of origin of life', is a rich source of biological and chemical diversity. Marine floras include microflora (bacteria, actinobacteria, cyanobacteria and fungi), microalgae, macroalgae (seaweeds), and flowering plants (mangroves and other halophytes). Marine organisms have unique properties as they are exposed to extreme marine environmental conditions. This vast marine floral resource offer a great way for discovery of new drugs which can fight deadly diseases like cancer, acquired immune deficiency syndrome (AIDS), arthritis, etc. Sea has got plenty of metabolites and other resources in living or dead form. Thermo-stable proteases, lipases, esterases, and starch and xylan degrading enzymes have been actively sought from bacterial and archaeal hyperthermophilic marine microorganisms. Marine cyanobacteria appear to be potential sources for production of vitamins such as B complex group and vitamin-E. The carotenoids and phycobiliprotein pigments of cyanobacteria have commercial value as natural food colouring agents, as feed additives, as enhancers of the color of egg yolks, to improve the health and fertility of cattle, as drugs and in the cosmetic industries. Some anti-HIV activity has been observed with the compounds extracted from Lyngbya lagerhaimanii and Phormidium tenue. Thus an attempt to review few marine derived biomedical resources was done emphasizing that with the advent of modern technologies it is anticipated that the marine environment will become an invaluable source of novel compounds in the future.
\end{abstract}

Keywords: Marine Floras, Hyperthermophilic, Marine Cyanobacteria, Lyngbya Lagerhaimanii

\section{Introduction}

Although more than 30000 diseases have been clinically described, less than one-third of these can be treated symptomatically and only a few can be cured. New therapeutic agents are urgently needed to treat medical needs that are currently unmet. Natural products once played a major role in drug discovery $[1,2]$. The marine environment covers more than $70 \%$ of the world's surface.

\subsection{Ocean Habitats}

In Ocean Habitats, there are two major marine provinces: the benthic (bottom) and the pelagic (water column). The benthic environment is divided by depth into the: Intertidal zone, Sublittoral zone, Bathyal zone, Abyssal zone, and the Hadal zone. The pelagic environment is divided into the Neritic Zone and the Oceanic Zone.

The five major kingdoms in the ocean are: Monera,
Protista, Fungi, Metaphyta and Metazoa (Animalia). Monera are the bacteria and blue-green algae. Protista are singlecelled organisms with a nucleus. Fungi are abundant in the intertidal zone and are important in decomposition. Metaphyta are the plants that grow attached to the sea floor. Metazoa include all multicellular animals in the ocean.

\subsection{Marine Organisms as Biomedical Resources}

Since the beginning of mankind nature has been contributing considerably to drug discovery for human beings by providing remedial treatments. One of nature's treasures is the marine biotope, which occupies almost three quarters of the earth's surface. Marine natural products play an increasingly important role in biomedical research and drug development [1]. Marine derived bioactive compounds help in the treatment of many diseases such as cancer, AIDS, inflammatory conditions, and a large variety of viral, bacterial and fungal diseases. Majority of the marine natural products have been isolated from sponges, coelenterates, tunicates, 
opisthobranch molluscs, echinoderms, bryozoans and a wide variety of marine microorganisms in their tissues [2].

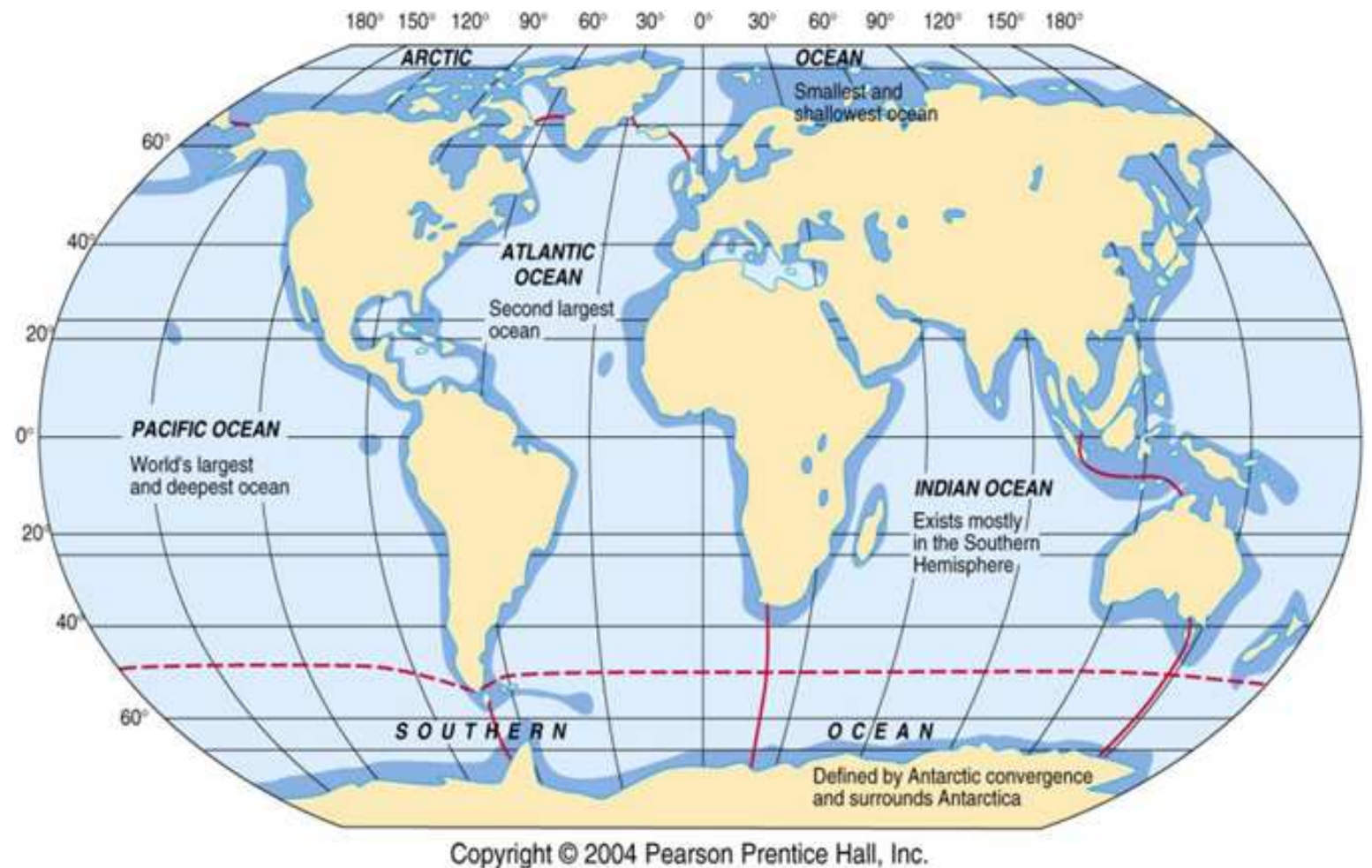

Copyright @ 2004 Pearson Prentice Hall, Inc.

Figure 1. Geography of Earth's Oceans.

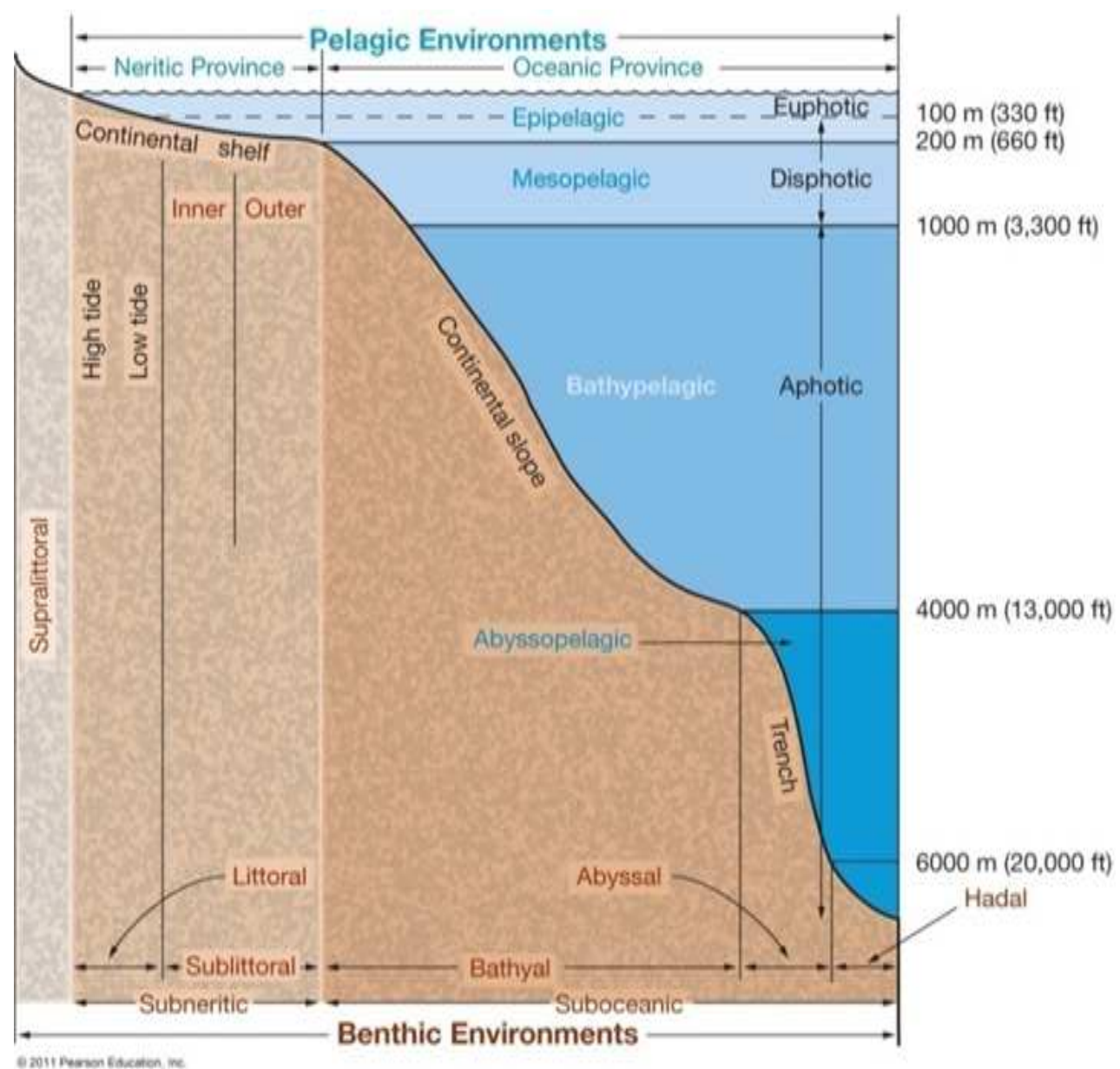

Figure 2. Divisions of the Marine Environment, Pelagic Environment and Benthic Environments. 


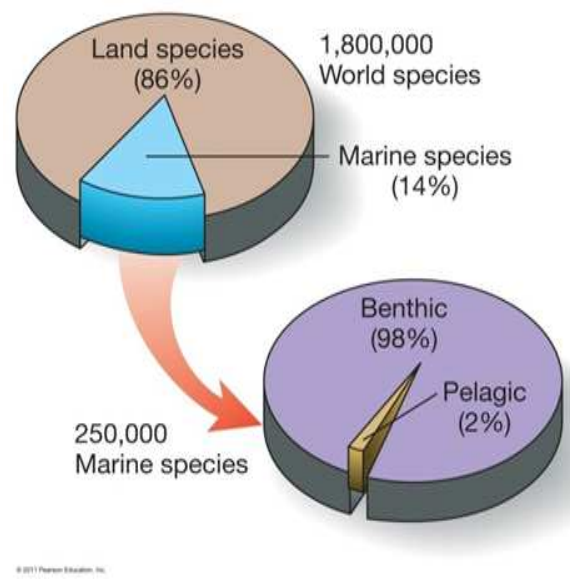

Figure 3. Classification of Marine Organisms.

\subsubsection{Marine Algae}

Microalgae, the most primary and simply-organized members of marine plant life, are rich sources of food ingredients, such as $\beta$-carotene, Vitamins $\mathrm{C}, \mathrm{A}, \mathrm{E}, \mathrm{H}, \mathrm{B} 1$, $\mathrm{B} 2, \mathrm{~B} 6$ and $\mathrm{B} 12$, astaxanthin, polysaccharides and polyunsaturated fatty acids [3]. Toxins from dinoflagellates. are useful tools to investigate the structure and function of ion channels on cell membranes or to elucidate the mechanism of tumor promotion based on their specific inhibitory action against protein phosphatases.

\subsubsection{Marine Invertebrates}

Marine Sponges, the most primitive multicellular invertebrates, considered as a gold mine for isolation of promising bioactive compounds for human welfare. Interestingly, cytarabine (Cytostar-U) also known as Ara-C, a compound isolated from the Caribbean sponge Cryptotheca crypta currently being used with other anticancer drugs in the treatment of acute myelocytic leukaemia (AML) [4]. In addition to potential anticancer applications, the bioactive compounds of sponges have a myriad of activities ranging from antibiotic activity including anticoagulant, antithrombin, anti-inflammatory HIV-protease inhibitory, HIV reverse transcriptase inhibitory, as well as imunomodulatory activities [5].

\subsubsection{Molluscs, Echinoderms and Crustaceans}

Bioactive peptides obtained from the fermented blue mussel and oyster sauces significantly decrease hypertension whilst ground abalone and its shells are used for treating eye diseases [6]. The Pacific oyster contains a substance which may help diabetics by promoting the secretion of insulin.

\subsubsection{Marine Fish}

The nutritional benefits of fish consumption are due to the presence of proteins, unsaturated essential fatty acids, minerals (for example, calcium, iron, selenium and zinc), and vitamins, namely Vitamin A, B3, B6, B12, E and D. Research has also shown that peptides derived from fermented fish following enzymatic treatment may be useful therapeutics for the treatment of many common acute and chronic diseases such as viral infections, hypertension, cancer and Alzheimer's disease [7]. Fish collagen may also be used in bone treatment as an alternative to mammalian collagen which is known to be immunogenic [8].

\section{Methodology}

\subsection{Technology in Exracting Marine Bioactive Compounds}

Sample collection is the first and important step which is much more difficult in the marine environment than if working with terrestrial organisms. Selective extractions, separations, and purification procedures are followed. If the pure compound shows really interesting activity, further pharmacological assays (in vitro, in vivo, toxicity, tolerated dose, and so on) and chemical work (structure modification, preparation of analog, structure-activity relationship, total synthesis, cultivation, etc.) should be carried out in order to enter the development step. After biomass extraction with an adequate solvent system, the fist step in the isolation of a natural compound from the main extract or broth usually consists of a sequential gradient partition with solvents. Next the fractions of low or medium polarity contain lipophilic organic compounds that can usually be separated by standard normal or reverse phase column chromatography (CC) and/or MPLC and finally HPLC to get the individual components. The high-polarity fractions are chromatographed on Sephadex, and the individual components of the active fraction are further separated by countercurrent chromatography (i.e., DCCC) and/or HPLC on the appropriate column packing $(\mathrm{C} 18$, amino, cyano, etc.). Once the individual components are isolated in a pure form, efforts should be focused on the disclosure of their structure. This is carried out by spectroscopic methods, mainly MS and NMR (1D and 2D). Potent therapeutic agents are isolated from marine organisms using a conventional culturing method. Examples include AraC (the drug name of which is cytarabine) a clinically useful anticancer agent and bryostatin.

\subsection{Metagenomics}

Metagenomics affords an efficient and inexpensive method to capture this chemical diversity. Metagenomics is providing renewed insights into what chemical diversity means and how it originates in the ocean.

\section{Results}

\subsection{Bioactive Compounds Derived from Marine Organisms}

Bioactive compounds derived from marine organisms has been reviewed in results. Anti-cancer agents have been isolated from algae, sponges, jellyfish, corals, shark cartilage and shellfish which are also summarised at one point. Commercially available marine by products have also been searched from the literature. 
Table 1. Marine derived bioactive compounds [9, 10, 11, 12].

\begin{tabular}{|c|c|c|c|}
\hline Category & Bioactive molecule & Major marine source & Health perspectives \\
\hline \multirow[t]{2}{*}{$\begin{array}{l}\text { Protein and } \\
\text { Peptides }\end{array}$} & Collagen & $\begin{array}{l}\text { Fish (albacore tuna, silver-line grunt, } \\
\text { brown-backed toadfish, hake, trout, } \\
\text { lingcod, catfish, rainbow trout, yellow sea } \\
\text { bream and common horse mackerel etc.). }\end{array}$ & $\begin{array}{l}\text { Anti-oxidant, anti-hypertensive and anti-skin-aging } \\
\text { activities. }\end{array}$ \\
\hline & Albumin & Molluscs, crustaceans, low-fat fish & Anticoagulant and antioxidant properties \\
\hline \multirow{3}{*}{$\begin{array}{l}\text { Poly } \\
\text { Saccharides }\end{array}$} & Fucans and fucanoids & $\begin{array}{l}\text { Cell walls of brown algae, sea urchin eggs, } \\
\text { sea cucumbers }\end{array}$ & $\begin{array}{l}\text { Anticoagulant, antiviral, antithrombotic, proliferative and } \\
\text { anti-inflammatory }\end{array}$ \\
\hline & $\begin{array}{l}\text { Chitin, chitosan, and } \\
\text { derivatives }\end{array}$ & Shrimp, crab, lobster, prawn and krill & $\begin{array}{l}\text { Increase dietary fiber, reduce lipid absorption, antitumor, } \\
\text { bactericidal and fungicidal activities }\end{array}$ \\
\hline & Carrageenan & $\begin{array}{l}\text { Macroalgae e.g., K. alvarezii, } \\
\text { E. denticulatum and B. gelatinum }\end{array}$ & Anti-HIV activity and anticoagulant properties \\
\hline Fatty acids & Omega-3 fatty acids & Almost all marine sources & $\begin{array}{l}\text { Numerous health benefits (e.g., visual and } \\
\text { neurodevelopment, reduce risk of cardiovascular problems, } \\
\text { ameliorate diseases such as arthritis and hypertension) }\end{array}$ \\
\hline \multirow{3}{*}{ pigments } & $\begin{array}{l}\text { Carotenoids: } \beta \text {-carotene, and } \\
\text { lutein }\end{array}$ & $\begin{array}{l}\text { Dunaliella salina, Sarcina maxima, } \\
\text { Chlorella protothecoides, Chlorella } \\
\text { vulgaris and Haematococcus pluvialis }\end{array}$ & $\begin{array}{l}\text { Vitamin A precursors, antioxidants, anti-carcinogenic and } \\
\text { anti-inflammatory }\end{array}$ \\
\hline & Phlorotannins & $\begin{array}{l}\text { The most abundant polyphenols found } \\
\text { in the marine brown algae }\end{array}$ & Antioxidant activity \\
\hline & Chlorophylls & S. platensis and A. flos-aquae & Anticancer activity, natural source of pigmentation \\
\hline \multirow[b]{2}{*}{$\begin{array}{l}\text { Marine } \\
\text { enzymes }\end{array}$} & Lipases & $\begin{array}{l}\text { Atlantic cod, seal, salmon, sardine, Indian } \\
\text { mackerel and red sea bream }\end{array}$ & Numerous uses in the fats and oils industry \\
\hline & $\begin{array}{l}\text { Gastric proteases; pepsins, } \\
\text { gastricsins and chymosins } \\
\text { Serine and cysteine } \\
\text { Proteases }\end{array}$ & $\begin{array}{l}\text { Various fish body viscera like atlantic cod, } \\
\text { carp, harp seals, and tuna etc. } \\
\text { Crustaceans, mollusks and short-finned } \\
\text { squid }\end{array}$ & $\begin{array}{l}\text { Cold renneting milk and fish feed } \\
\text { digestion aid } \\
\text { Preventing unwanted color changes in food products, meat } \\
\text { tenderizing, curing of Herring, squid fermentation }\end{array}$ \\
\hline $\begin{array}{l}\text { Vitamins and } \\
\text { Minerals }\end{array}$ & $\begin{array}{l}\text { Fat and water soluble } \\
\text { vitamins, iron, iodine, } \\
\text { manganese and zinc }\end{array}$ & $\begin{array}{l}\text { Almost all marine sources. Seaweeds are } \\
\text { rich sources of vitamins and minerals }\end{array}$ & $\begin{array}{l}\text { Vitamins and minerals perform many essential functions in } \\
\text { the body, for example, they provide transport inside cells } \\
\text { and also serve as cofactors during metabolic processes }\end{array}$ \\
\hline
\end{tabular}

Table 2. Antitumor agents from marine sources [13].

\begin{tabular}{|c|c|c|c|c|}
\hline Organism & Metabolite & Location & Discoverer & Current status \\
\hline Bryozoan: Bugula neritina & Bryostatin I & Gulf of California & Pettit, Arizona State Univ. & $\begin{array}{l}\text { In Phase I/IIclinical trials in } \\
\text { US/Europe; NCI sponsored } \\
\text { trials. }\end{array}$ \\
\hline Sea hare: Dolabella auricularia & Dolastatin 10 & Indian Ocean & Pettit, Arizona State Univ. & $\begin{array}{l}\text { In Phase I/IIclinical trials in US; } \\
\text { NCI sponsored trials. }\end{array}$ \\
\hline $\begin{array}{l}\text { Tunicate: Ecteinascidia } \\
\text { turbinate }\end{array}$ & Ecteinascidin 743 & Caribbean & Rinehart, Univ. Illinois & $\begin{array}{l}\text { Licensed to Pharma Mar S. A. } \\
\text { In Phase II clinical trials in } \\
\text { Europe and in US. }\end{array}$ \\
\hline Tunicate: Aplidium albicans & $\begin{array}{l}\text { Dehydro-didemnin B } \\
\text { [Aplidine] }\end{array}$ & Mediterranean & Rinehart, Univ Illinois & Licensed to Pharma Mar S. A. \\
\hline Gastropod: Elysia rubefescens & Kahalalide F & Hawaii & Scheuer, Univ. Hawaii & Licensed to Pharma Mar S. A. \\
\hline Sponge: Discodermia dissoluta & Discodermolide & Caribbean & $\begin{array}{l}\text { Gunasekera \& Longley, } \\
\text { HBOI }\end{array}$ & Licensed to Novartis. \\
\hline Sponge: Lissodendoryx sp. & Isohomo-halichondrin B & New Zealand & $\begin{array}{l}\text { Munro \& Blunt; Univ. } \\
\text { Canterbury, NZ }\end{array}$ & Licensed to Pharma Mar S. A. \\
\hline $\begin{array}{l}\text { Actinomycete: } \\
\text { Micromonospora marina }\end{array}$ & Thiocoraline & Mozambique Strait & Canedo, Spain & Licensed to Pharma Mar S. A. \\
\hline $\begin{array}{l}\text { Tunicate: Didemnum } \\
\text { granulatum }\end{array}$ & Isogranulatimide & Atlantic [Brazil] & $\begin{array}{l}\text { Andersen \& Bjerinck, Univ, } \\
\text { British Columbia \& Brazil }\end{array}$ & Licensed to Kinetik, Canada. \\
\hline Sponge: Jaspis sp & Bengamide & Fiji & $\begin{array}{l}\text { Crews et al. Univ. } \\
\text { California, Santa Cruz }\end{array}$ & $\begin{array}{l}\text { Synthetic derivative licensed to } \\
\text { Novartis. }\end{array}$ \\
\hline Sponge: Cymbastella sp. & Hemiasterelins A \& B & Papua New Guinea & $\begin{array}{l}\text { Andersen, Univ. British } \\
\text { Columbia }\end{array}$ & Licensed to Wyeth-Ayerst. \\
\hline
\end{tabular}

Table 3. Commercially available marine by products.

\begin{tabular}{llll}
\hline Product & Application & Original source & Method of production \\
\hline Ara-A & Antiviral drug & Marine sponge, Cryptotethya cryta & microbial fermentation of \\
Ara-C & Anticancer drug & Marine sponge, Cryptotethya cryta & Chemical synthesis of analog \\
Okadaic acid & Molecular probe: phosphatase inhibitor & Dinoflagellate & Cell culture \\
Manoalide & Molecular probe: phospholipase A2 & Marine sponge, Luffariella variabilis & Wild harvest of sponge \\
\hline
\end{tabular}




\begin{tabular}{|c|c|c|c|}
\hline Product & Application & Original source & Method of production \\
\hline & inhibitor & & \\
\hline Ara-A & Antiviral drug & Marine sponge, Cryptotethya cryta & $\begin{array}{l}\text { microbial fermentation of } \\
\text { analog }\end{array}$ \\
\hline Vent ${ }^{\circledR}$ DNA polymerase & Polymerase chainreaction enzyme & Deep sea hydrothermal vent bacterium & Recombinant protein \\
\hline $\begin{array}{l}\text { Formulaid }{ }^{\circledR} \text { (Martek } \\
\text { Biosciences, Columbia, MD) }\end{array}$ & $\begin{array}{l}\text { Fatty acids used as additivein infant } \\
\text { formula nutritional supplement }\end{array}$ & Marine microalga & Cell culture \\
\hline Aequorin & Bioluminescent calcium indicator & Bioluminescent jellyfish, Aequora victoria & Recombinant protein \\
\hline $\begin{array}{l}\text { Green Fluorescent Protein } \\
\text { (GFP) }\end{array}$ & Reporter gene & Bioluminescent jellyfish, Aequora victoria & Recombinant protein \\
\hline
\end{tabular}

\subsection{Adaptations of Marine Organisms}

Marine organisms show more adaptations compared to human (Figure 4). Important adaptations include

1. Camouflage through color patterns

2. Countershading - dark on top, light on bottom

3. Disruptive coloration - large bold patterns, contrasting colors make animal blend into background

4. High surface area to volume ratio and unusual appendages are important adaptations of marine organisms. Viscosity and Streamlining Adaptations offers less resistance to fluid flow. These adaptations help the marine organism to adapt to narrow range of temperature in oceans (Figure 5).

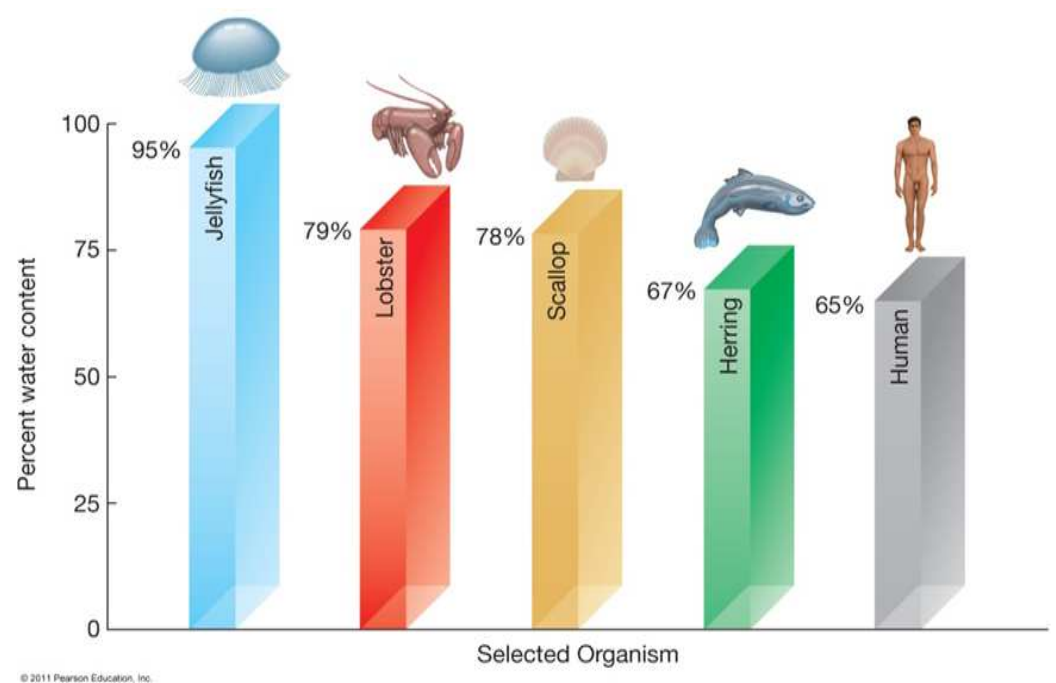

Figure 4. Adaptations of Marine Organisms.

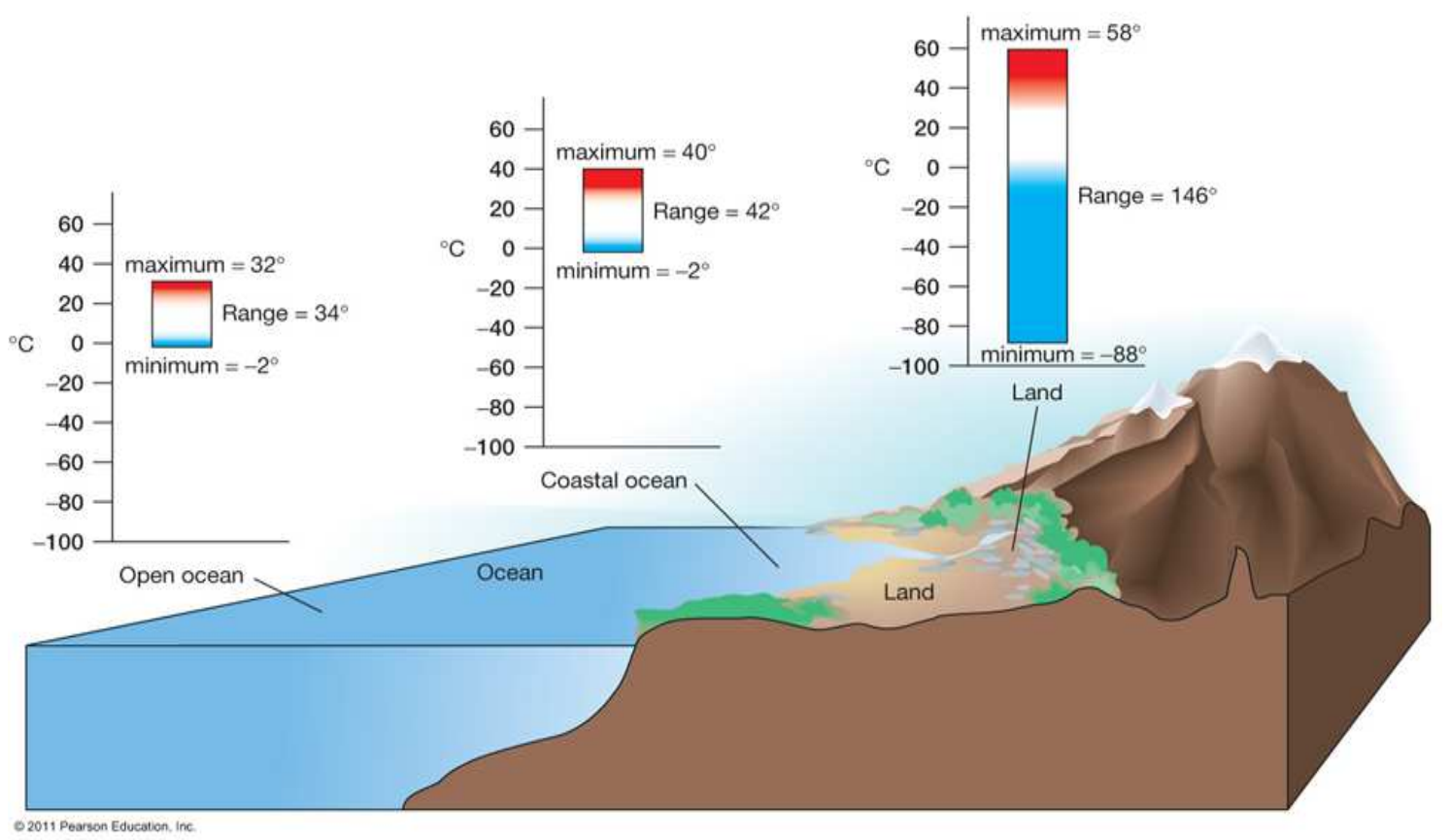

Figure 5. Narrow range of temperature in oceans. 


\subsection{Drugs from the Sea}

Drugs from marine animals was compared with other terrestrial animals, terrestrial plants, marine plants and micro organisms and it found to be comparatively very high. Brown algae proved a rich biomedical resource. Chemical diversity clearly shows varied applications in medical field.

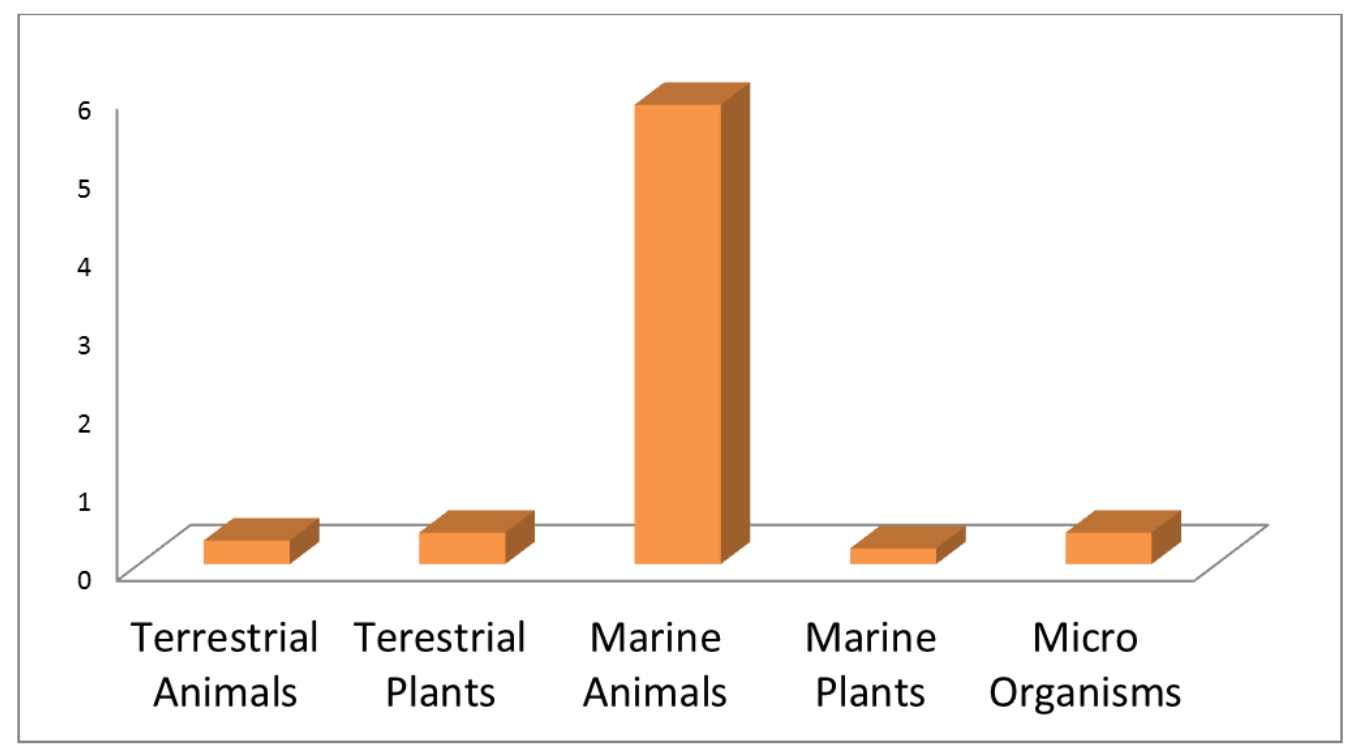

Figure 6. Percent Compounds Tested by NCI with Significant Cytotoxicity.

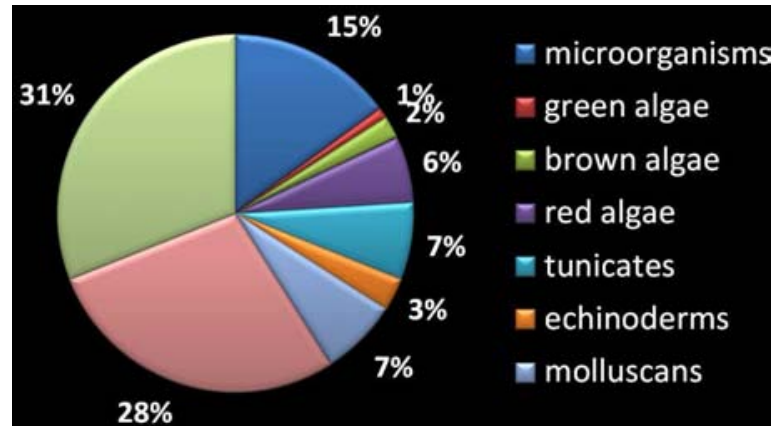

Figure 7. Vast Majority of Drugs from Marine Invertebrates.

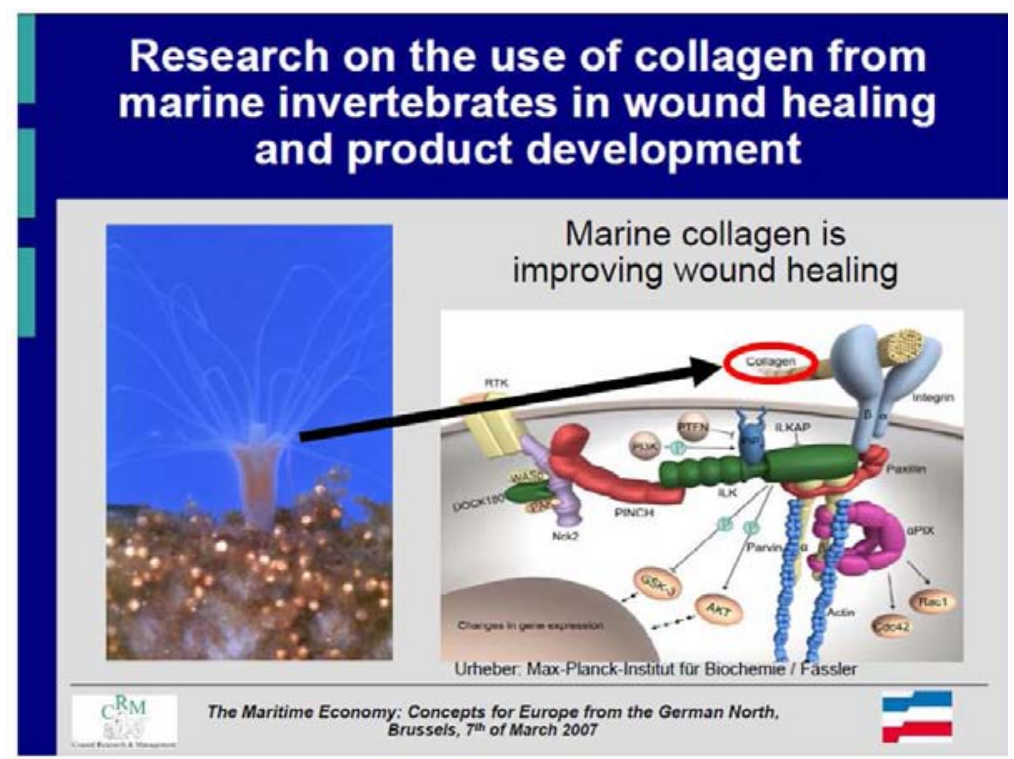

Figure 8. Marine invertebrates as biomedical resource. 


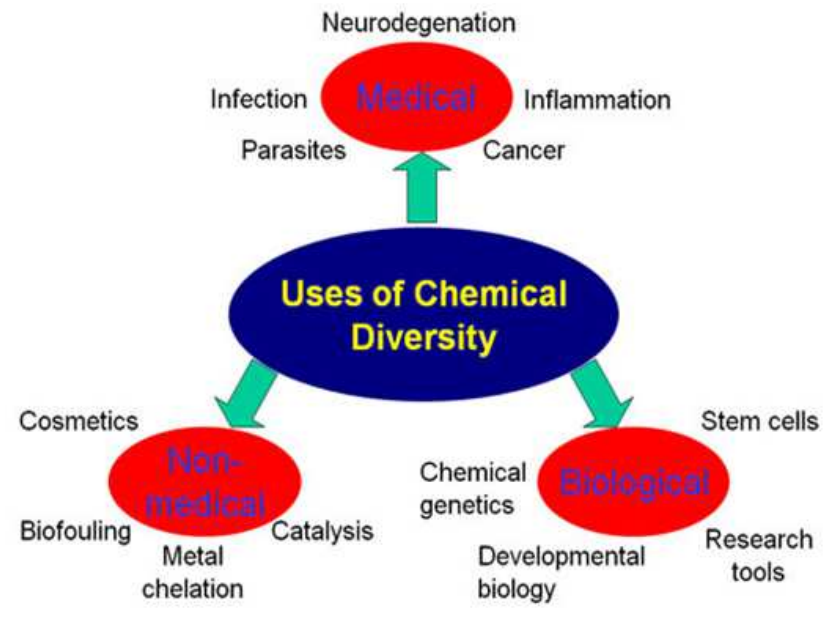

Figure 9. Uses of chemical diversity.

\section{Discussion}

Marine life constitutes almost $80 \%$ of the world biota with thousands of bioactive compounds and secondary metabolites derived from marine invertebrates such as tunicates, sponges, molluscs, bryozoans, sea slugs and many other marine organisms. These bioactive molecules and secondary metabolites possess antibiotic, antiparasitic, antiviral, anti inflammatory, antifibrotic and anticancer activities. They are also inhibitors or activators of critical enzymes and transcription factors, competitors of transporters and sequestrants that modulate various physiological pathways. The sources of new leads for treatment of many diseases such as cancer, AIDS, inflammatory conditions, and a large variety of viral, bacterial and fungal diseases. Metagenomics affords an efficient and inexpensive method to capture this chemical diversity.

Bioremediation speeds the natural degradation process. It is being used to clean up sewage, sludge, seafood wastes, and toxins in marine areas. By using genetically modified marine organisms, scientists are able to clean up or contain oil spills. For example, this approach achieved great success after the oil spill from the Exxon Valdez in Alaska. Research done on the Eastern Oyster has also produced the discovery of Polyaspartic Acid, which helps plants take in more nutrients from the soil without using as much fertilizer. This is helping to stimulate agriculture even further.

\section{Conclusion}

The marine environment provides a broad range of diverse habitats from which novel sources of natural products can be derived. Studies from around the world have shown that marine organisms produce a diverse array of metabolites with pharmaceutical properties used in the treatment of many diseases such as cancer, AIDS, inflammatory conditions, and a large variety of viral, bacterial and fungal diseases. Still there is a lot to unravel regarding the richness of marine environment. Thus an attempt to review few marine derived biomedical resources was done emphasizing that with the advent of modern technologies it is anticipated that the marine environment will become an invaluable source of novel compounds in the future. Still there is a lot to unravel regarding the richness of marine environment.

Need methods of recognizing species. Morphology has limited use.

Genetic markers (e.g., DNA sequences, length fragment polymorphisms in mitochondrial DNA) allow identification of populations

With the advent of modern technologies it is anticipated that the marine environment will become an invaluable source of novel compounds in the future.

\section{References}

[1] Demain AL, Zhang L: Natural products and drug discovery. In Natural Products: Drug Discovery and Therapeutics Medicines. Edited by Zhang L, Demain A. Humana Press; 2005: 3-32.

[2] Hill, R. T.; Fenical, W. Pharmaceuticals from marine natural products: Surge or ebb? Curr. Opin. Biotechnol. 2010, 21, 777-779.

[3] Yap, C. Y.; Chen, F. Polyunsaturated fatty acids: Biological significance, biosynthesis, and production by microalgae and microalgae-like organisms. In Algae and Their Biotechnological Potential; Chen, F., Jiang, Y., Eds.; Kluwer Academic Publishers: Dordrecht, The Netherlands, 2001; pp. 1-32.

[4] Thoms, C.; Schupp, P. J. Chemical defense strategies in sponges: A review. In Porifera Research: Biodiversity, Innovation and Sustainability; Custodio, M. R., Hajdu, G. L., Hajdu, E., Muricy, G., Eds.; IMOS: Rio de Janeiro, Museu Nacional, Brazil, 2007; pp. 627-637.

[5] Gochfeld DJ, El Sayed KA, Yousaf M, Hu JF, Bartyzel P, Dunbar DC, Wilkins SP, Zjawiony JK, Schinazi RF, Schlueter Wirtz $S$ et al.: Marine natural products as lead anti-HIV agents. Mini Rev Med Chem 2003, 3: 401-424.

[6] Kim, S.; Pallela, R. Medicinal Foods from Marine Animals: Current Status and Prospects. Adv. Food Nutr. Res. 2012, 65, $1-9$.

[7] Vo, T. S.; Kim, S. K. Potential anti-HIV agents from marine resources: An overview. Mar. Drugs 2010, 8, 2871-2892.

[8] Wijesekara, I.; Kim, S. K. Angiotensin-i-converting enzyme (ACE) inhibitors from marine resources: Prospects in the pharmaceutical industry. Mar. Drugs 2010, 8, 1080-1093.

[9] Di-Bernardini, R.; Harnedy, P.; Bolton, D.; Kerry, J.; O’Neill, E.; Mullen, A. M.; Hayes, M. Antioxidant and antimicrobial peptidic hydrolysates from muscle protein sources and byproducts. Food Chem. 2011, 124, 1296-1307.

[10] Agyei, D.; Danquah, K. Industrial-scale manufacturing of pharmaceutical-grade bioactive peptides. Biotechnol. Adv. 2011, 29, 272-277.

[11] Harris, K. A.; Hill, A. M.; Kris-Etherton, P. M. Health benefits of marine derived omega-3 fatty acids. ACSMS Health Fit. J. 2010, 14, 22-28. 
[12] Honypattarakere, T.; Cherntong, N.; Wickienchot, S.; Kolida, S.; Rastall, R. A. In vitro prebiotic evaluation of exopolysaccharides produced by marine isolated lactic acid bacteria. Carbohydr. Polym. 2012, 87, 846-852.

[13] Newman DJ, Cragg GM: The discovery of anticancer drugs from natural sources. In Natural Products: Drug Discovery and Therapeutics Medicines. Edited by Zhang L, Demain A. Humana Press; 2005: 275-294.

[14] Streit WR, Schmitz RA: Metagenomics - the key to the uncultured microbes. Curr Opin Microbiol 2004, 7: 492-498. This paper is a remarkable overview of the recent progress in metagenome technology.

[15] Kim EY, Kim DG, Kim YR, Hwang J, Nam TJ, Kong IS: An improved method of protein isolation and proteome analysis with Saccharina japonica (Laminariales) incubated under different pH conditions. J. Appl. Phycol. 2011, 23, 123-130.

[16] Jiao G, Yu G, Zhang J, Ewart HS: Chemical structures and bioactivities of sulfated polysaccharides from marine algae. Mar. Drugs 2011, 9, 196-233.

[17] Kim S, Pallela R. Medicinal Foods from Marine Animals: Current Status and Prospects. Adv. Food Nutr. Res. 2012, 65, $1-9$.

[18] Herpandi NH, Rosma A, Wan NWA. The Tuna Fishing Industry: A New Outlook on Fish Protein Hydrolysates. Compr. Rev. Food Sci. Food Saf. 2011, 10, 195-207.

[19] Vo TS, Kim SK. Potential anti-HIV agents from marine resources: An overview. Mar. Drugs 2010, 8, 2871-2892.

[20] Wijesekara I, Kim SK. Angiotensin-i-converting enzyme (ACE) inhibitors from marine resources: Prospects in the pharmaceutical industry. Mar. Drugs 2010, 8, 1080-1093.

[21] Hu GP, Yuan J, Sun L, She ZG, Wu JH, Lan XJ, Zhu X, Lin YC, Chen SP. Statistical research on marine natural products based on data obtained between 1985 and 2008. Mar. Drugs 2011, 9, 514-525. 